\title{
Genetic diversity of promising 'conilon' coffee clones based on morpho-agronomic variables
}

\author{
JOÃO ANTONIO D. GILES ${ }^{1}$, FÁBIO L. PARTELLI ${ }^{1}$, ADÉSIO FERREIRA ${ }^{2}$, JOICE \\ P. RODRIGUES ${ }^{1}$, GLEISON OLIOSI ${ }^{1}$ and FERNANDO H. LIMA E SILVA ${ }^{3}$ \\ ${ }^{1}$ Centro Universitário Norte do Espírito Santo, Universidade Federal do Espírito Santo/UFES, \\ Rodovia BR 101 Norte, Km 60, Bairro Litorâneo, 29932-540 São Mateus, ES, Brazil \\ ${ }^{2}$ Centro de Ciências Agrárias, Universidade Federal do Espírito Santo/UFES, Alto \\ Universitário, s/n, Guararema, 29500-000 Alegre, ES, Brazil \\ ${ }^{3}$ Instituto Federal Goiano, Campus Rio Verde, Rodovia Sul Goiana, Km 01, s/n, Zona Rural, 75901-970 Rio Verde, GO, Brazil
}

Manuscript received on July 9, 2017; accepted for publication on August 7, 2017

\begin{abstract}
Knowledge of the genetic variability of a population is essential to guide its preservation and maintenance in addition to increasing the efficiency of genetic breeding programs. On this basis, this study was conducted to evaluate the genetic diversity of Coffea canephora genotypes using multivariate statistical procedures applied to a set of morpho-agronomic variables. The materials employed in this study constitute a crop located in Vila Valério - ES, Brazil, where the genotypes are arranged in a randomized-blocks experimental design with four replicates. Significant differences were detected by the F test at the $1 \%$ or $5 \%$ probability levels among the genotypes for all evaluated traits, demonstrating heterogeneity of genetic constitution in the studied population, which is favorable to breeding, as it indicates the possibility to identify superior and divergent individuals. Based on the generalized Mahalanobis distance, the most divergent combinations were obtained between genotypes 23 and 10 (256.43) and 23 and 17 (250.09). The clusters formed by Tocher's optimization and the UPGMA hierarchical method agreed, both similarly grouping the genotypes into three clusters. Of the analyzed traits, mature fruit weight (19.08\%), yield (15.50\%), plant diameter $(12.42 \%)$, and orthotropic-shoot internode length (10.94\%) were the most efficient to explain the dissimilarity among the genotypes.
\end{abstract}

Key words: Coffea canephora, dissimilarity, multivariate analysis, plant breeding.

\section{INTRODUCTION}

The coffee crop occupies over 11 million hectares, and its product is one of the most valuable of the world economy, with a production sector involving more than 80 countries (Denoeud et al. 2014,

Correspondence to: João Antônio Dutra Giles

E-mail: joao_antoniodg@hotmail.com

* Contribution to the centenary of the Brazilian Academy of Sciences.
Mohanan et al. 2014). The plant that originates this commodity belongs to the family Rubiaceae, which in turn comprises over 11,000 species, ordered into 550 genera (Robbrecht and Manen 2006), one of which is Coffea. According to Davis et al. (2011), this genus has at least 124 species, wherein C. arabica Linnaeus and C. canephora Pierre ex A. Froehner are the two of highest commercial prominence, accounting for approximately 58\% 
and $42 \%$ of the 148 bags of $60 \mathrm{~kg}$ produced in 2016 across the globe (ICO 2017).

Today, the species $C$. canephora, also known as 'conilon' or 'robusta' coffee, is cultivated at low to medium elevations in the intertropical regions of Africa, America, and Asia. It adapts well to warmer climates without major variations in temperature, with precipitation greater than 2,000 $\mathrm{mm} \mathrm{yr}^{-1}$ (Montagnon et al. 2012, Cubry et al. 2013).

The species $C$. canephora is diploid $(2 \mathrm{n}=2 \mathrm{x}=$ 22 ) and mostly allogamous, of gametophytic selfincompatibility (Carvalho et al. 1991) of monogenic nature; i.e., it is bound to a single " $\mathrm{S}$ " locus, with at least three alleles interacting (Conagin and Mendes 1961). This mechanism prevents the pollen grain carrying a certain allele from fertilizing any ovule carrying the same allele, thereby preventing selfpollination and/or cross of individuals with similar alleles.

Therefore, the natural reproduction of the species generates highly heterozygous individuals and populations with high genetic variability. In this regard, the characterization and exploitation of genetic variability within the species $C$. canephora may reveal genetic resources of great value both for production systems and for its use in genetic breeding programs. Rodrigues et al. (2014) reported that the coffee breeding programs aiming at productivity, aggregating agronomic traits for resistance to pests and diseases, and plants of short height and adapted to local climate and soil conditions.

Genetic variability, the raw material of breeding programs, can be estimated by multivariate analyses, which are based on differences between accessions, simultaneously integrating multiple pieces of information from a set of traits. In this sense, the analysis of genetic diversity is important in that it provides parameters for the identification of the parents whose cross produces a greater heterotic effect, to heighten the possibilities of obtaining offspring with superior features (Cruz et al. 2014).
Studies on the genetic diversity of coffee adopting multivariate analyses have been carried out by many researchers, both for $C$. canephora (Fonseca et al. 2006, Ivoglo et al. 2008, Rocha et al. 2013, Dalcomo et al. 2015, Silva et al. 2015, Covre et al. 2016), and C. arabica (Dias et al. 2005, Guedes et al. 2013, Silva et al. 2013, Teixeira et al. 2013, Moura et al. 2015, Rodrigues et al. 2016). Information in this regard provides bases to be used in breeding programs for the species.

Given the above-described scenario, this study was carried out to investigate the genetic diversity of promising registered $C$. canephora genotypes using multivariate statistical procedures employed on a set of morpho-agronomic traits.

\section{MATERIALS AND METHODS}

\section{STUDIED POPULATION AND DESCRIPTION OF THE EXPERIMENT}

We evaluated 30 C. canephora genotypes, 29 of which were propagated vegetatively via cuttings and one via seminiferous tubules (Table I).

The crop was implemented in May 2012 in the municipality of Vila Valério - ES, Brazil (18 ${ }^{\circ} 58^{\prime} 05^{\prime}$ ' S latitude and $40^{\circ} 20^{\prime} 02$ ' W longitude; $150 \mathrm{~m}$ asl), with an average annual temperature of $23{ }^{\circ} \mathrm{C}$. The climate in the region is tropical, characterized by hot and wet summers and dry winters, classified as an Aw type, according to the Köppen classification (Alvares et al. 2013), The average annual precipitation in 2015 was 1,200 mm (ANA 2015).

The genotypes were arranged in randomizedblocks experimental design with four replicates in which the treatments corresponded to the different genotypes and each experimental unit contained four plants. The plants were planted under a spacing of $2.2 \mathrm{~m}$ between rows and $1.2 \mathrm{~m}$ between plants, establishing a density of 3,086 plants per hectare, with four stems per plant. The sprinkler irrigation system was adopted. 
TABLE I

Coffea canephora genotypes evaluated in Vila Valério - ES, Brazil. Promising registered genotypes.

\begin{tabular}{cccccc}
\hline Number & Genotype & Number & Genotype & Number & Genotype \\
\hline 1 & Vitória V1 & 11 & Beira Rio 6 & 21 & $18 \mathrm{a}$ \\
2 & Vitória V2 & 12 & Beira Rio 8 & 22 & Baiano 4a \\
3 & Vitória V4 & 13 & Beira Rio 9 & 23 & Pirata \\
4 & Vitória V5 & 14 & Beira Rio 10 & 24 & Cownga \\
5 & Vitória V7 & 15 & Bamburral & 25 & Verdim 1 \\
6 & Vitória V8 & 16 & Clementino & 26 & Verdim R \\
7 & Vitória V9 & 17 & P.Seminífera & 27 & P2 \\
8 & Vitória V10 & 18 & Emcapa 153 & 28 & P1 \\
9 & Beira Rio 3 & 19 & Emcapa 143 & 29 & LB1 \\
10 & Beira Rio 5 & 20 & 22a & 30 & A1 \\
\hline
\end{tabular}

Note: Genotypes from 1 to 8 belong to variety "Vitória Incaper 8142"; Genotypes 18 and 19 belong to variety Emcapa 8131.

\section{MORPHO-AGRONOMIC CHARACTERIZATION}

The following 15 morpho-agronomic traits were evaluated: height $(\mathrm{PH})$ and diameter (PD) of the plant at 477 days after planting (DAP); orthotropicshoot internode length (OSI), measured after the plant reached its adult stage, in full production; weight (WMF), volume (VMF), and density (DMF) of the mature fruit, measured in fruits collected in the second harvest; grain processing rate (PR), corresponding to the ratio between mature fruit and processed grain $(\% \mathrm{w} / \mathrm{w})$; average yield of the 2014 and 2015 crops (YLD), expressed in bags $(60 \mathrm{~kg}$ ) per hectare; total chlorophyll index (CI), obtained using a manual chlorophyll meter (clorofiLOG $\left.{ }^{\circledR}\right)$; leaf length (LL), width (LW), and area (LA), the last of which was estimated by the methodology proposed by Partelli et al. (2006); leaf dry mass (LDM); and leaf specific mass (LSM), calculated as the ratio between dry mass and leaf area. For these leaf morphology assessments, we collected ten leaves per plot from the third and/or fourth pair of newly developed leaves from plagiotropic shoots located at the middle third of the plants. Collections took place when the plants were at approximately two years and eight months of age.

\section{STATISTICAL ANALYSIS}

The data were subjected to analysis of variance, and the existence of variability was tested by the F test. For the study of genetic diversity, we determined the generalized Mahalanobis $\left(\mathrm{D}^{2}\right)$ distance matrix, which was used as a dissimilarity measure for the cluster analysis of the genotypes by Tocher's optimization method and the UPGMA (Unweighted Pair Group Method using Arithmetic Averages) hierarchical method. We also obtained the relative contribution of the traits for the genetic diversity among the $C$. canephora genotypes by Singh (1981)'s method. All of the aforementioned analyses were performed using the resources of Genes software (Cruz 2013).

\section{RESULTS AND DISCUSSION}

According to the analysis of variance, significant differences were detected by the $\mathrm{F}$ test at the $1 \%$ or $5 \%$ probability levels among the C. canephora genotypes for all the morpho-agronomic traits assessed (Table II).

This fact reveals heterogeneity in the genetic composition of the studied population, which is important for analyses of genetic diversity and also 
TABLE II

Summary of analysis of variance for 15 morpho-agronomic traits evaluated in 30 promising registered Coffea canephora genotypes Vila Valério - ES, Brazil.

\begin{tabular}{|c|c|c|c|c|}
\hline \multirow{2}{*}{ Traits } & \multicolumn{2}{|c|}{ Mean Square } & \multirow{2}{*}{ Average } & \multirow{2}{*}{ CV (\%) } \\
\hline & Genotype & Residual error & & \\
\hline $\mathrm{PH}$ & 177.1452 & $28.1079^{* *}$ & 78.95 & 6.72 \\
\hline $\mathrm{PD}$ & 574.8038 & $76.6649^{* *}$ & 107.67 & 8.13 \\
\hline OSI & 0.5013 & $0.0633^{* *}$ & 2.81 & 8.96 \\
\hline PSI & 0.5795 & $0.0611^{* *}$ & 3.06 & 8.07 \\
\hline MFW & 0.0838 & $0.0055^{* *}$ & 0.95 & 7.79 \\
\hline MFV & 0.0823 & $0.0067^{* *}$ & 0.91 & 9.00 \\
\hline MFD & 0.0124 & $0.0057^{* *}$ & 1.06 & 7.14 \\
\hline PR & 15.9533 & $2.4831^{* *}$ & 24.84 & 6.34 \\
\hline YLD & 893.9544 & $79.3112^{* *}$ & 64.35 & 13.84 \\
\hline CI & 46.5976 & $22.6726^{* *}$ & 70.93 & 6.71 \\
\hline LL & 1.9338 & $0.6492^{* *}$ & 14.71 & 5.48 \\
\hline LW & 0.3855 & $0.2236^{*}$ & 5.69 & 8.31 \\
\hline LA & 118.4598 & $38.9397^{* *}$ & 56.96 & 10.95 \\
\hline LDM & 17494.4300 & $6071.7240^{* *}$ & 700.77 & 11.12 \\
\hline LSM & 4.1057 & $1.7074^{* *}$ & 12.40 & 10.54 \\
\hline
\end{tabular}

** and ${ }^{*}$, significant at the 1 and 5\% probability levels, respectively, by the F test. PH: plant height at 477 DAP (cm); PD: plant diameter at 477 DAP (cm); OSI: orthotropic-shoot internode length $(\mathrm{cm})$; PSI: plagiotropic-shoot internode length (cm); MFW: mature fruit weight $(\mathrm{g})$; MFV: mature fruit volume $(\mathrm{mL})$; MFD: mature fruit density; PR: grain processing rate $(\% \mathrm{w} / \mathrm{w}) ; \mathrm{YLD}$ : average yield of the 2014 and 2015 crops (bags ha ${ }^{-1}$ ); CI: chlorophyll index; LL: leaf length (cm); LW: leaf width (cm); LA: leaf area $\left(\mathrm{cm}^{2}\right)$; LDM: leaf dry mass (mg); LSM: leaf specific mass $\left(\mathrm{mg} \mathrm{cm}{ }^{-2}\right)$.

favorable to breeding, as it indicates the possibility of discriminating superior and divergent genotypes.

The coefficient of variation (CV), which expresses the residual standard deviation as a percentage of the overall mean, is frequently used to estimate the precision of experiments. In this study, values between 5.48 and $13.84 \%$ were found, with an average of $8.61 \%$ (Table II). According to PimentelGomes (2009), all of these are classified as low (CV $<10 \%)$ or medium $\left(\mathrm{CV}_{\mathrm{e}}<20 \%\right)$, demonstrating good experimental precision in the evaluations performed, as stated by Cruz et al. (2014).

The maximum and minimum dissimilarity values for each one of the $30 \mathrm{C}$. canephora genotypes, obtained based on the generalized Mahalanobis $\left(\mathrm{D}^{2}\right)$ distance, showed varied magnitude, with values ranging between 5.003 and
256.433, indicating broad genetic diversity in the studied population (Table III).

Dalcomo et al. (2015) evaluated 22 genotypes of conilon coffee from the breeding program of Incaper and also found elevated magnitude for genetic dissimilarity, with values between 7.32 and 168.37 .

The highest average dissimilarity (145.72) was observed in genotype 23 (Pirata), which was present in $93.3 \%$ of the most dissimilar pairs; i.e., it was the genotype most distant from 28 of the total 30 under evaluation. The most divergent combinations were obtained between genotypes 23 and 10 (256.43) and between 23 and 17 (250.09). Genotypes 6 and 15 , on the other hand, were the most similar, as they exhibited the shortest distance (5.00) between the least dissimilar pairs. 
TABLE III

Average, maximum, and minimum dissimilarity for 30 promising registered Coffea canephora genotypes based on generalized Mahalanobis distance $\left(\mathrm{D}^{2}\right)$, considering 15 morpho-agronomic traits ${ }^{1}$. Vila Valério - ES, Brazil.

\begin{tabular}{|c|c|c|c|c|c|}
\hline \multirow{2}{*}{ Genotype } & \multirow{2}{*}{$\begin{array}{c}\text { Average } \\
\text { dissimilarity }\end{array}$} & \multicolumn{2}{|c|}{ Maximum dissimilarity } & \multicolumn{2}{|c|}{ Minimum dissimilarity } \\
\hline & & Genotype & Distance & Genotype & Distance \\
\hline 1 & 44.56455 & 23 & 159.139842 & 11 & 16.338563 \\
\hline 2 & 42.37869 & 23 & 171.486173 & 6 & 8.380784 \\
\hline 3 & 42.86718 & 23 & 160.405796 & 6 & 5.309058 \\
\hline 4 & 45.72179 & 23 & 138.149287 & 7 & 15.940578 \\
\hline 5 & 44.36534 & 23 & 121.645149 & 19 & 18.294495 \\
\hline 6 & 34.70369 & 23 & 136.208307 & 15 & 5.003676 \\
\hline 7 & 27.95849 & 23 & 108.498885 & 19 & 8.787921 \\
\hline 8 & 62.69844 & 23 & 156.749164 & 5 & 32.325622 \\
\hline 9 & 54.94184 & 23 & 152.761368 & 14 & 25.273979 \\
\hline 10 & 66.19208 & 23 & 256.432611 & 17 & 25.995628 \\
\hline 11 & 42.73313 & 23 & 156.990554 & 21 & 7.673506 \\
\hline 12 & 85.16450 & 17 & 125.760347 & 22 & 31.701214 \\
\hline 13 & 35.69210 & 23 & 82.246938 & 7 & 12.512651 \\
\hline 14 & 29.94187 & 23 & 131.795703 & 7 & 8.899016 \\
\hline 15 & 39.34052 & 23 & 131.736855 & 6 & 5.003676 \\
\hline 16 & 43.51350 & 23 & 115.003605 & 7 & 16.578355 \\
\hline 17 & 59.97461 & 23 & 250.088603 & 20 & 22.282136 \\
\hline 18 & 44.66841 & 23 & 172.942595 & 25 & 10.809870 \\
\hline 19 & 34.89041 & 23 & 125.698329 & 7 & 8.787921 \\
\hline 20 & 48.43194 & 23 & 224.798217 & 2 & 21.668399 \\
\hline 21 & 36.51560 & 23 & 144.725625 & 11 & 7.673506 \\
\hline 22 & 43.97228 & 23 & 128.370045 & 7 & 16.221329 \\
\hline 23 & 145.71600 & 10 & 256.432611 & 30 & 76.313264 \\
\hline 24 & 44.18330 & 23 & 118.254270 & 14 & 15.618320 \\
\hline 25 & 47.43553 & 23 & 187.401413 & 18 & 10.809870 \\
\hline 26 & 73.29632 & 23 & 126.203228 & 5 & 34.716500 \\
\hline 27 & 41.08602 & 23 & 150.359086 & 14 & 14.049508 \\
\hline 28 & 37.21266 & 23 & 93.131116 & 7 & 12.989153 \\
\hline 29 & 45.66103 & 23 & 142.243507 & 18 & 13.493561 \\
\hline 30 & 49.40958 & 10 & 89.263453 & 28 & 15.767228 \\
\hline
\end{tabular}

${ }^{1}$ Plant height and diameter at 477 DAP; length of the orthotropic - and plagiotropic- shoot internodes; weight, volume, and density of mature fruit; grain processing rate (\% w/w); average yield of the 2014 and 2015 crops; chlorophyll index; leaf length, width, and area; leaf dry mass; and leaf specific mass.

It should be stressed that the genotypes belonging to variety Vitoria (V1, V2, V4, V5, V7, V8, V9, V10, and Emcapa 153) did not necessarily show the lowest distances, combining with each other, which corroborates the results obtained by Fonseca et al. (2006) in an evaluation of 32 genotypes of conilon coffee belonging to three clonal varieties. These authors remarked that crosses of greater interest are not always found among germplasms of distinct varieties. 
Clustering by Tocher's optimization method, using the generalized Mahalanobis distance $\left(D^{2}\right)$ as the genetic dissimilarity measure, for 15 morphoagronomic traits, separated the 30 genotypes into three groups (Table IV).

The first group consisted of 28 genotypes, including approximately $93 \%$ of the total genotypes studied. This fact is related to the high dissimilarity presented by genotype 23, which was higher by the order of $192.4 \%$ as compared with the overall mean of the average dissimilarity (Table III). Similar results were found by Silva et al. (2015), who evaluated 56 genotypes of the genus Robusta and also found $91 \%$ of the individuals associated with the first group.

Genotypes 12 (Beira Rio 8) and 23 (Pirata) were, separately, the second and the third groups, respectively, indicating that these are the most divergent. Tocher's optimization method minimizes the intra-group distance and maximizes the intergroup distance (Cruz et al. 2014); in this way, more divergent combinations should be obtained with genotypes allocated in distinct groups.

Studies reporting the use of Tocher's method for clustering C. canephora genotypes were also conducted by Fonseca et al. (2006), who worked with 32 clones of three clonal varieties; by Ivoglo et al. (2008), with 21 progenies of half-siblings; and by Covre et al. (2016), with 34 promising genotypes, who reported the formation of three, four, and eight groups, respectively.

TABLE IV

Clusters formed from 30 promising registered Coffea canephora genotypes, obtained by Tocher's method, based on generalized Mahalanobis distance $\left(D^{2}\right)$, considering 15 morpho-agronomic traits. Vila Valério - ES, Brazil.

\begin{tabular}{|c|c|}
\hline Groups & Genotype \\
\hline 1 & 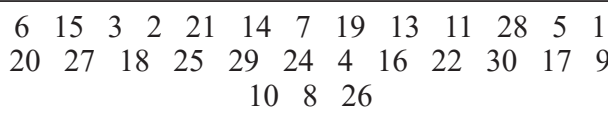 \\
\hline 2 & 12 \\
\hline 3 & 23 \\
\hline
\end{tabular}

Clustering by the UPGMA hierarchical method, using the generalized Mahalanobis distance $\left(D^{2}\right)$ as a measure of genetic dissimilarity, enabled the generation of the dendrogram illustrating the genetic distance among the studied genotypes. When the maximum dissimilarity limit of 50\% was established among genotypes for them to be included in the same group, three groups were formed (Figure 1).

The groups formed by the UPGMA method, assuming a maximum dissimilarity limit of $50 \%$ among the genotypes, were formed similarly to those generated by Tocher's method, increasing the consistency between the clustering methods. Similarities between Tocher's and UPGMA hierarchical method were also observed by Ivoglo et al. (2008), Guedes et al. (2013), and Covre et al. (2016), who established the maximum limits of dissimilarity among genotypes as $15 \%, 45 \%$, and $50 \%$, respectively

Except for genotypes 30 and 10, all the others that represented the most dissimilar parents based on the generalized Mahalanobis distance $\left(D^{2}\right)$ (Table III) were allocated in distinct groups by both Tocher's optimization (Table IV) and the UPGMA hierarchical method (Figure 1), increasing the reliability in the use of clusters to establish divergent combinations. Motta et al. (2014) evaluated $C$. arabica and $C$. canephora genotypes and also observed that the most dissimilar genotypes based on Jaccard's index were mostly allocated in distinct groups by UPGMA.

The study of the relative contribution of the 15 morpho-agronomic traits for genetic diversity among the 30 C. canephora genotypes, according to Singh (1981)'s method, showed values between 0.015 and $19.080 \%$ (Table V).

The traits that most contributed were mature fruit weight (19.08\%), average yield (15.50\%), plant diameter $(12.42 \%)$, and orthotropic-shoot internode length $(10.94 \%)$; these four variables accounted for $58 \%$ of the genetic divergence 


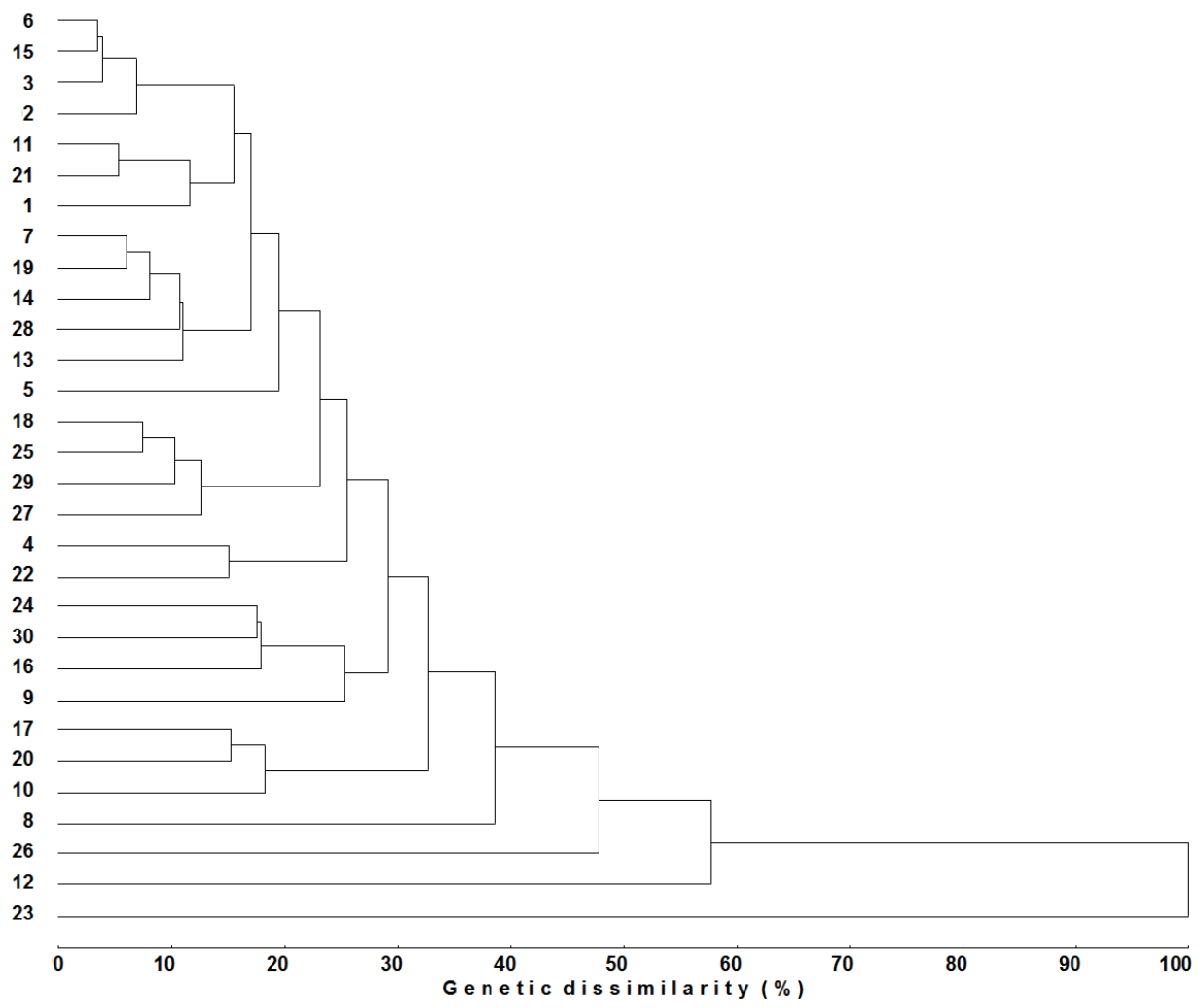

Figure 1 - Dendrogram representing the genetic dissimilarity among 30 promising registered Coffea canephora genotypes, obtained by the UPGMA cluster method, using generalized Mahalanobis distance $\left(\mathrm{D}^{2}\right)$, considering 15 morpho-agronomic traits. Note: cophenetic correlation coefficient (CCC): $87.27 \%$.

among the studied genotypes. Guedes et al. (2013) evaluated 27 traits in 12 accessions of coffee $(C$. arabica L.) var. Maragogipe and Ivoglo et al. (2008) evaluated 14 traits in 21 progenies of $C$. canephora half-siblings and observed yield as one of the traits that most contributed to divergence among the studied genotypes, with 22.7 and $10.5 \%$, respectively.

Fruit density (0.015), in turn, was the trait that least contributed to genetic diversity, and when it was discarded, it did not lead to significant alterations in the clusters obtained by Tocher's method; therefore, in subsequent evaluations, less importance can be assigned to this trait.

Figure 2 shows the standardized means for morpho-agronomic traits in each group formed by Tocher's optimization method. This graph allows us to know the traits that differentiate each group.
It is clear that among the traits of greatest relative contribution (Table V), those which characterize group 2 are fruits of larger weight and volume and lower grain processing rate. Group 3, in turn is characterized by plants with larger diameter and higher yield (Figure 2).

Despite the genetic diversity detected among the genotypes, breeders are usually interested only in the superior individuals with respect to some traits, with sufficient diversity to generate variability in the segregating population (Guedes et al. 2013). In $C$. canephora breeding programs, breeders aim at genotypes that, among other features, provide higher yields and produce larger grains (Ferreira et al. 2005). In this scenario, the genotypes from groups 2 and 3 showed to be promising, because in addition to their genetic diversity, they exhibit traits of agronomic interest (Figure 2). 
TABLE V

Relative contribution of $\mathbf{1 5}$ morpho-agronomic traits for genetic diversity in 30 promising registered Coffea canephora genotypes based on Singh (1981)'s method, using generalized Mahalanobis distance $\left(\mathrm{D}^{2}\right)$. Vila Valério - ES, Brazil.

\begin{tabular}{ccc}
\hline Traits & S.j & Value $(\%)$ \\
\hline MFW & 4125.755056 & 19.080 \\
YLD & 3352.028483 & 15.502 \\
PD & 2685.260696 & 12.418 \\
OSI & 2366.094264 & 10.942 \\
PSI & 1893.711330 & 8.758 \\
PR & 1728.743733 & 7.995 \\
LDM & 1542.608442 & 7.134 \\
PH & 1299.638652 & 6.010 \\
MFV & 968.399258 & 4.478 \\
CI & 602.932788 & 2.788 \\
LA & 382.716226 & 1.770 \\
LW & 272.011552 & 1.258 \\
LSM & 211.840563 & 0.980 \\
LL & 188.668397 & 0.872 \\
MFD & 3.284616 & 0.015 \\
\hline
\end{tabular}

PH: plant height at 477 DAP; PD: plant diameter at 477 DAP; OSI: orthotropic-shoot internode length; PSI: plagiotropicshoot internode length; MFW: mature fruit weight; MFV: mature fruit volume; MFD: mature fruit density; PR: grain processing rate; YLD: average yield of the 2014 and 2015 crops; CI: chlorophyll index; LL: leaf length; LW: leaf width; LA: leaf area; LDM: leaf dry mass; LSM: leaf specific mass.
After the evaluations, the materials called Beira Rio 8, Bamburral, Clementino, Pirata, Verdin $\mathrm{R}$ and $\mathrm{A} 1$ constituted a new variety called Tributum, which is registered by UFES. The average of four harvests of the six genotypes was 90.87 bags benefited $(60 \mathrm{~kg})$ per hectare.

\section{CONCLUSIONS}

There is genetic diversity among the 30 promising registered C. canephora evaluated here, indicating high potential for use in future breeding actions; genotypes Pirata (promising) and Beira Rio 8 (promising) were the most divergent. Tocher's and UPGMA hierarchical methods showed consistency in the grouping of genotypes, separating them similarly into two groups; of the analyzed traits, mature fruit weight, average productivity, plant diameter, and orthotropic-shoot internode length were the most efficient in explaining the dissimilarity among the genotypes.

\section{ACKNOWLEDGMENTS}

The authors would like to thank the Conselho Nacional de Desenvolvimento Científico e Tecnológico (CNPq) and Coordenação de Aperfeiçoamento de Pessoal de Nível Superior

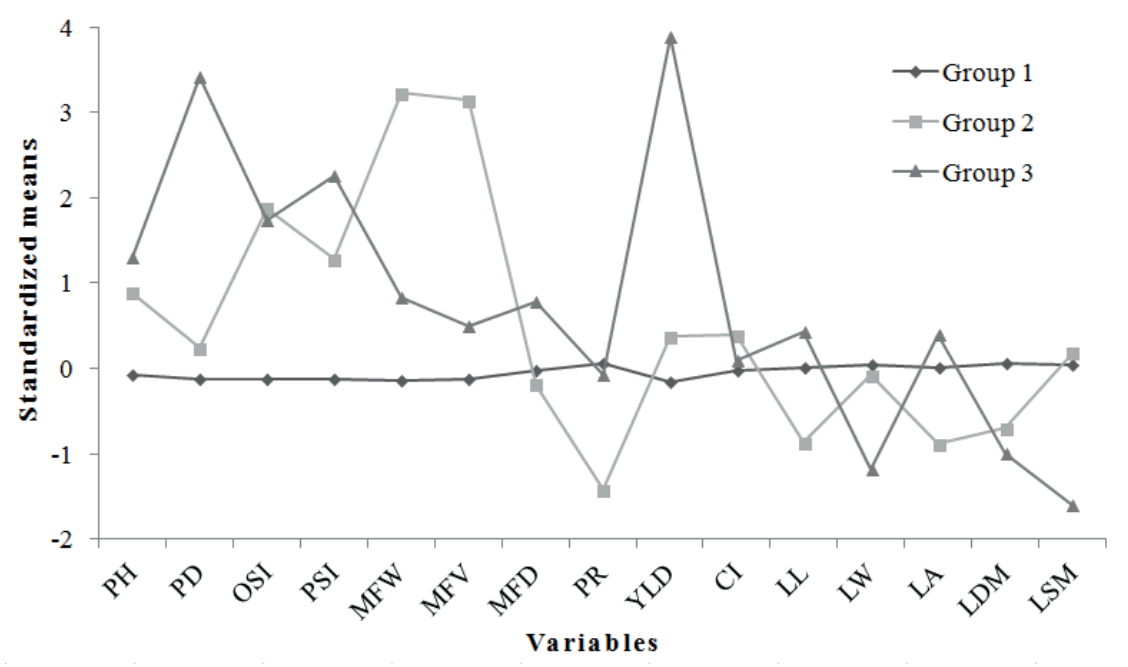

Figure 2 - Standardized means of the 15 morpho-agronomic traits for each group formed by Tocher's optimization method. Vila Valério - ES, Brazil. Promising registered genotypes. 
(CAPES) for financial support, as well as the owner of the land.

\section{REFERENCES}

ALVARES CA, STAPE JL, SENTELHAS PC, GONÇALVES JLM AND SPAROVEK G. 2013. Köppen's climate classification map for Brazil. Meteorol Z 22: 711-728.

ANA - AGÊNCIA NACIONAL DE ÁGUAS. 2015. A bacia do Rio Doce: características da bacia. Available at: $<$ http://www.ana.gov.br/cbhriodoce/bacia/caracterizacao. asp\#clima>. Accessed on Jan 19, 2015.

CARVALHO A, MEDINA FILHO HP, FAZUOLI LC, GUERREIRO FILHO O AND LIMA MMA. 1991. Aspectos genéticos do cafeeiro. Rev Bras Genet 14: 135183.

CONAGIN CHTM AND MENDES AJT. 1961. Pesquisas citológicas e genéticas em três espécies de Coffea. Auto-incompatibilidade em Coffea canephora Pierre ex Froehner. Bragantia 20: 787-804.

COVRE AM, CANAL L, PARTELLI FL, ALEXANDRE RS, FERREIRA A AND VIEIRA HD. 2016. Development of clonal seedlings of promising Conilon coffee (Coffea canephora) genotypes. Aust J Crop Sci 10: 385-392.

CRUZ CD. 2013. GENES - a software package for analysis in experimental statistics and quantitative genetics. Acta Sci Agron 35: 271-276.

CRUZ CD, CARNEIRO PCS AND REGAZZI AJ. 2014. Modelos biométricos aplicados ao melhoramento genético, $3^{\text {rd }}$ ed., Viçosa: UFV, 668 p.

CUBRY P, BELLINS F, POT D, MUSOLI P AND LEROY T. 2013. Global analysis of Coffea canephora Pierre ex Froehner (Rubiaceae) from the Guineo-Congolese region reveals impacts from climatic refuges and migration effects. Genet Resour Crop Evol 60: 483-501.

DALCOMO JM, VIEIRA HD, FERREIRA A, LIMA WL, FERRÃO RG, FONSECA AFA, FERRÃO MAG AND PARTELLI FL. 2015. Evaluation of genetic divergence among clones of conilon coffee after scheduled cycle pruning. Genet Mol Res 14: 15417-15426.

DAVIS, AP, TOSH J, RUCH N AND FAY MF. 2011. Growing coffee: Psilanthus (Rubiaceae) subsumed on the basis of molecular and morphological data; implications for the size, morphology, distribution and evolutionary history of Coffea. Bot J Linn Soc 167: 357-377.

DENOEUD F, CARRETERO-PAULET L, DEREEPER A, DROC G, GUYOT R, PIETRELLA M, ZHENG C, ALBERTI A, ANTHONY F AND APREA G. 2014. The coffee genome provides insight into the convergent evolution of caffeine biosynthesis. Science 345: 11811184.

DIAS FP, SOUZA CAS, MENDES ANG, CARVALHO SPN, RASO BSM AND BOTELHO CE. 2005. Caracterização de progênies do cafeeiro (Coffea arabica L.) selecionadas em Minas Gerais. Rev Ceres 299: 101-114.

FERREIRAA, CECON PR, CRUZ CD, FERRÃO RG, SILVA MF, FONSECAAFA AND FERRÃO MAG. 2005. Seleção simultânea de Coffea canephora por meio da combinação de análise de fatores e índices de seleção. Pesq Agropec Bras 40: 1189-1195.

FONSECA AFA, SEDIYAMA T, CRUZ CD, SAKAIYAMA NS, FERRÃO MAG, FERRÃO RG AND BRAGANÇA SM. 2006. Divergência genética em café conilon. Pesq Agropec Bras 41: 599-605.

GUEDES JM, VILELA DJM, REZENDE JC, SILVA FL, BOTELHO CE AND CARVALHO SP. 2013. Divergência genética entre cafeeiros do germoplasma Maragogipe. Bragantia: 72: 127-132.

ICO - INTERNATIONAL COFFEE ORGANIZATION. 2017. Dados Históricos. Available at: <http://www.ico.org/ prices/po-production.pdf $>$. Accessed on Jan 25, 2017.

IVOGLO MG, FAZUOLI LC, OLIVEIRA ACB, GALLO PB, MISTRO JC, SILVAROLLA MB AND TOMABRAGHINI M. 2008. Divergência genética entre progênies de café robusta. Bragantia 67: 823-831.

MOHANAN S, SATYANARAYANA KV, SRIDEVI V, GOWDA K, GIRIDHAR P, CHANDRASHEKAR A AND RAVISHANKAR GA. 2014. Evaluating the effect and effectiveness of different constructs with a conserved sequence for silencing of Coffea canephora N-methyltransferases. J Plant Biochem Biotechnol 23: 399-409.

MONTAGNON C, CUBRY P AND LEROY T. 2012. Amélioration génétique du caféier Coffea canephora Pierre: connaissances acquises, stratégies et perspectives. Cah Agric 23: 143-153.

MOTTA LB, SOARES TC, FERRÃO MAG, CAIXETA ET, LORENZONI RM AND SOUZA NETO JD. 2014. Molecular characterization of Arabica and Conilon coffee plants genotypes by SSR and ISSR markers. Braz Arch Biol Technol 57: 728-735.

MOURA WM, SOARES YJB, AMARAL JÚNIOR AT, LIMA PC, MARTINEZ HEP AND GRAVINA GA. 2015. Genetic diversity in arabica coffee grown in potassium-constrained environment. Ciênc Agrotec 39: 23-31.

PARTELLI FL, VIEIRA HD, DETMANN E AND CAMPOSTRINI E. 2006. Estimativa da área foliar do cafeeiro a partir do comprimento da folha. Rev Ceres 53: 204-210.

PIMENTEL-GOMES P. 2009. Curso de Estatística Experimental. $15^{\text {th }}$ ed., Piracicaba: FEALQ, $451 \mathrm{p}$.

ROBBRECHT E AND MANEN JF. 2006. The major evolutionary lineages of the coffee family (Rubiaceae, angiosperms). Combined analysis (nDNA and cpDNA) to infer the position of Coptosapelta and Luculia, and supertree construction based on rbcL, rps16, tnrL-trnF, and 
atpB-rbcL data. A new classification in two subfamilies, Cinchonoideae and Rubioideae. Syst Geogr P1 76: 85-146. ROCHA RB, SANTOS DV, RAMALHO AR AND TEIXEIRA AL. 2013. Caracterização e uso da variabilidade genética de banco ativo de germoplasma de Coffea canephora Pierre ex Froehner. Coffee Sci 8: 478-485.

RODRIGUES WP, VIEIRA HD, BARBOSA DHSG, SOUSA FILHO GR AND PARTELLI FL. 2014. Agronomic performance of arabica coffee genotypes in northwest Rio de Janeiro State. Genet Mol Res 13: 5664-5673.

RODRIGUES WP, VIEIRA HD, TEODORO PE, PARTELLI FL AND BARBOSA DHSG. 2016. Assessment of genetic divergence among coffee genotypes by Ward-MLM procedure in association with mixed models. Genet Mol Res 15:1-7.
SILVA FL, BAFFA DCF, OLIVEIRA ACB, PEREIRA AA AND BONOMO VS. 2013. Integração de dados quantitativos e multicategóricos na determinação da divergência genética entre acessos de cafeeiro. Bragantia 72: 224-229.

SILVA FL, BAFFA DCF, REZENDE JC, OLIVEIRA ACB, PEREIRA AA AND CRUZ CD. 2015. Variabilidade genética entre genótipos de café robustas no estado de Minas Gerais. Coffee Sci 10: 20-27.

SINGH D. 1981. The relative importance of characters affecting genetic divergence. Indian J Genet $\mathrm{Pl} \mathrm{Br}$ 41: 237 245.

TEIXEIRAAL, GONÇALVES FMA, REZENDE JC, ROCHA RB AND PEREIRA AA. 2013. Análise e componentes principais em caracteres morfológicos de café arábica em estádio juvenil. Coffee Sci 8: 205-210. 